\title{
Biological Warfare and Snake Venom for Poliomyelitis and ALS: The Little Known Entwined History of Failed Ethics and a Reasonable Therapeutic Hypothesis
}

\author{
Victor M Rivera, MD, FAAN* \\ Department of Neurology, Baylor College of Medicine, Houston, Texas, USA
}

*Corresponding author: Victor M Rivera, MD, FAAN, Distinguished Emeritus Professor, Department of Neurology, Baylor College of Medicine, Houston, Texas, USA

\begin{abstract}
This paper describes a complicated history taken place during World War II (WWII) when military intentions for acquiring biological weapon superiority knowledge was obtained in some cases through atrocious investigations in human beings disregarding ethical and moral principles. After the war, Murray Sanders (1910-1988), a young military officer and American scientist became incidentally entwined with the U.S. military concern over the Japanese bacteriological knowledge, unbeknown by the Allies that was being acquired through human experiments. In a second stage of his career (between 1949 and 1983), Sanders investigated the potential therapeutic characteristics of snake venom, obtained several U.S. patents on the formulation and an Investigational New Drug (IND) license from the Food and Drug Administration (FDA). While he was well-intentioned and cared for his patients, Sanders utilized protocols non-sanctioned by Independent Ethics Committees and openly administered detoxified snake venom neurotoxin or Modified Neurotoxin (MNT) to patients with poliomyelitis and later used it in Amyotrophic Lateral Sclerosis (ALS). While Sanders reported "partial" efficacy of MNT in ALS this was not confirmed with placebo-controlled, IRB-approved clinical trials. Two well-designed placebo-controlled clinical trials performed by independent institutions sanctioned by the FDA and approved by their respective Institutional Review Boards did not yield positive results. Findings were reported in the neurological literature. Later in life Sanders was requested to testify in a Congressional Hearing on the WWII Japanese bacteriological warfare experiments and the U.S. strategy to condone culpability of war crimes in exchange for military information. This article reflects on a scientific effort spanning through several epochs and personae interacting with diverse philosophies and different objectives performing research in human beings.
\end{abstract}

\section{Introduction}

Amyotrophic Lateral Sclerosis (ALS) is a serious, degenerative neuromuscular disorder, clinically characterized by an inexorable progressive course usually leading to a fatal outcome a few years from the outset of symptoms. The disease produces atrophy of upper and lower motor neurons along with degeneration of corticospinal and corticobulbar pathways. The etiology it is unknown but it appears that a causal multifactorial situation plays a role where genetic mutations and disordered cellular glutamate metabolism occurs. Over the course of time multiple etiologies and theories on the cause of ALS have been proposed while the disease traditionally has remained as an incurable disease. Derived from current progress on the understanding of molecular mechanisms and performance of appropriate clinical trials, new therapies are available at present time: An inhibitor of extracellular glutamate release and an agent that controls neuronal damage by oxidative stress.

This paper reviews the history of a dark period on human experimentation during WWII which involved incidentally a young American military officer and scientist, Murray Sanders. During the post-war process Sanders was commissioned to obtain (albeit unsuccessfully) information on bacteriological weaponry from the Japanese investigators who apparently had experimented on prisoners utilizing horrific protocols. After the war collective international condemnation attached to punitive court procedures from the "Subsequent" (Medical)

Citation: Rivera VM (2019) Biological Warfare and Snake Venom for Poliomyelitis and ALS: The Little Known Entwined History of Failed Ethics and a Reasonable Therapeutic Hypothesis. Int J Neurol Neurother 6:092. doi.org/10.23937/2378-3001/1410092

Accepted: October 12, 2019: Published: October 14, 2019

Copyright: (C) 2019 Rivera VM, et al. This is an open-access article distributed under the terms of the Creative Commons Attribution License, which permits unrestricted use, distribution, and reproduction in any medium, provided the original author and source are credited. 
Nuremberg Trials in Europe [1] addressing Nazi "scientific" crimes, and the Military Tribunals for the Far East (Japan) in 1946, more humane and appropriate guidelines (Code for research conduct) developed for human investigations, molded by the Declaration of Helsinki (1963) [2] and later on by the Belmont report (1957).

In modern history warfare the principal conflagrates have raced to acquisition of weapons of mass destruction (nuclear, chemical, biological) aiming for military strategic superiority. WWII (1939-1945) was the unfortunate scenario of indiscriminate utilization of such level of assault on soldiers and civil populations. Weapons using infectious microbes had been used in reduced scale during the first War, but massive deployment reached its peak in the first half of the $20^{\text {th }}$ century despite its prohibition by the Geneva Convention in 1925 [3]. Unwilling prisoners and vulnerable subjugated individuals were utilized for biologic experimentation with the purpose to refine the technology to produce military bacteriological devices.

In a second phase of his career, Sanders focused his academic and scientific efforts to treat poliomyelitis and later ALS, utilizing compounds from detoxified snake venoms he denominated Modified Neurotoxin (MNT) and argued it had antiviral properties. While the poliovirus had been identified since the early part the $20^{\text {th }}$ Century, a "slow-virus" causality had been proposed for ALS during the 1960's-1970's. These therapies were initially openly administered to poliomyelitis and ALS patients without the sanction from an Ethics Board or 'Human Investigations Committees' (now Institutional Review Boards) and without being challenged by data from controlled trials. Implementation of strict guidelines regarding investigation on human beings took several years before strict stipulations (including informed consent) were fully functional and understood.

\section{Japanese Human Biological Experimentation}

The Imperial Japanese Army invaded Manchuria in 1931 and established the subjugated state of Manchukuo. The occupation lasted until the end of WWII. A large facility disguised as an "Epidemic Prevention and Water Purification Department" or Unit 731 of the Japanese Kwantung Army and the Ministry of Health, was installed in Pinfang, a small village outside the city of Harbin [4]. Close to 12,000 men, women and children, including Chinese, Mongolians, White Russians and possibly a few American prisoners of war died as unwilling victims of Biological experimentation conducted in the secret laboratories and prisons of Unit 731.

Subjects were infected with diverse microbial agents then vivisected anaesthetized to study their internal organs before decomposition occurred [5]. Approximately 270,000 Chinese soldiers and civilians were killed with anthrax, typhus, diphtheria, bubonic plague and other infections propagated and disseminated by the scientists working at Unit 731 by contaminating water supply plants, dropping bacteriological bombs and utilizing rats vectors [6].

Under the command of General Shiro Ishii 3000 bacteriologists, researchers, engineers and guards worked at Unit 731, the largest biological weapon research center in the world at that time [7]. Ishii was a prominent scientist educated at Kyoto University and Professor of Immunology at the Army Medical College in Tokyo. As a protegee of Sadado Araki, Minister of The Army and Pince Yasuhito, brother of Hiroito, Emperor of Japan, Ishii had performed extensive research on biological warfare particularly on anthrax employed by the Germans during the first was to kill U.S. military horses [8].

When the defeat of Japan was imminent, Ishii ordered the destruction of the Unit 731 compound, the materials and files of experiments, and the killing of 150 remaining prisoners. He bound his subordinates to an oath of secrecy dispersing the group back to Japan.

After the Japanese surrendered in September 2, 1945, General Douglas MacArthur was named Supreme Commander of the Allied Powers and de facto ruler of Japan. Increasing rumors of the activities at Unit 731 and the immediate initiation of the War Crimes Trials by the International Military Tribunal for the Far East enabled a massive hunt for Shiro Ishii and the members of the bacteriological research units.

\section{U.S. Probes and Condescension}

Despite the 1925 ban from the Geneva Convention, the U.S. had started its own research in potential biological weapons in 1943 at Camp Detrick, MD, a 1200acre military installation. Lt. Col. Murray Sanders was a 33-year-old microbiologist with an MD degree from Rush Medical College (1931) and training at Columbia University where he became faculty member before joining the Army in 1943. He performed classified investigations [9] designing laboratory techniques to advance freezing-dry Botulin toxin, hence being able to be delivered by projectiles over any enemy territory. Sanders gained recognition from his superiors for his accomplishments and his repeated warnings of the possibility of the U.S. West coast being attacked by the Japanese with anthrax bombs transported by transoceanic balloons [10]. By the end of 1945 Ishii and some of his collaborators were captured. Sanders was dispatched to interrogate Ishii and associates to obtain as much information as possible on the activities of Unit 731 and the rumored immense biological warfare knowledge the group had accumulated. On arrival Sanders was greeted at dock site by Ryoishi Naito, an English-speaking Japanese academic-researcher from Tokyo. Naito had convinced General MacArthur's staff to be assigned as translator for the arriving American scientist. The U.S. 
military had limited capabilities to communicate and access to reliable Japanese translators during the early days of the occupation. Unbeknownst to all (particularly Sanders) was the fact that Naito had been a student and admirer of Ishii at the Army Medical College in Tokyo becoming later his right-hand in a bacteriological satellite facility of Unit 731 located at the Shinjuku District in Tokyo. As an Assistant Professor in 1939, before the war, Naito had been sent to the Rockefeller Institute for Medical research in New York to obtain a yellow fever virus strain with the excuse to create a vaccine for Japanese people. He appeared unannounced and despite an introduction letter from the Military Attaché of the Japanese Embassy in Washington, DC, the request was refused by Wilbur Sawyer the director of the laboratory [11].

For nine weeks through the deceiving translation of Naito Sander's interrogation of General Ishii did not produce any results. Sander's inquiries on experiments in human subjects were totally stonewalled. With the increasing frustration of the Americans, Sanders suggested to General MacArthur a change in strategy: Promise immunity against war crimes to Ishii and his associates. MacArthur agreed [12].

Sanders began feeling ill and was ordered back to Camp Detrick. He was diagnosed with tuberculosis which incapacitated him for two years. Lt. Col. Arvo Thompson was sent to continue the interrogations while Ishii was placed under house arrest. Thompson's work was followed by another Camp Detrick's scientist, Dr. Norbert H. Fell. A "deal" was finally reached regarding exchange of data for immunity. The information was considered by the State War Navy Coordination Committee (SWNCC) responsible for overseeing the war crimes trial in Japan "to be retained in intelligence channels and not to be employed as war crime evidence". Dr. Edwin 8. Hill, chief of the basic sciences division at Camp Detrick in 1947, emphasized de data's extraordinary military value as "such information could not be obtained in our own laboratories because of samples attached to human investigation" [9]. President Truman agreed in 1948 to grant immunity to Ishii and his cohorts [13].

None of the scientists that worked at Unit 731 was ever tried (Tokyo Trials, 1946-1948) [5]. The entire affair was kept classified by the U.S. Government until 1993, but as late as 2006 the National Archives still did not show all the documents pertaining to the secret medical Japanese experimentation activities [14].

In the late 1940's Ishii lectured in Maryland on bioweapons. There is no accurate documentation about his activities during his last years in Japan, but he died a free man at age 67 from throat cancer [15].

Naito held several biological industry leadership positions during Japan's post-war re-structuration period.
Parlayed by his experience with freeze-drying technology Naito founded the immensely profitable commercial Japan's Blood Bank in 1951 (which procured plasma to the U.S. military during the Korean War, 1950-1953) and later the Green Cross Corporation, a billion-dollar enterprise [16]. Naito died in 1998. His association with the activities of Unit 731 were never mentioned.

In 1985 Sanders was requested to testify at a U.S. Congressional Hearing in Washington, DC, on his recall of interaction with the leaders of Unit 731. In press interviews he acknowledged he had been "duped" [17].

\section{Snake Venom, Poliomyelitis and ALS}

After Sanders recovered from tuberculosis in 1947 he retired from the Army and became Chairman of the Department of Medical Research at the University of Miami, position he held until 1957. During his tenure he met and befriended Bill Haast (1910-2011), owner and Director of the 'Miami Serpentarium and Laboratories'. For decades Haast had extracted ("milked") venom from poisonous snakes and marketed it for diverse medicinal remedies for pain, arthritis and as antivenom sera distributed by pharmaceutical companies in the Far East. Sanders became fascinated by the potential therapeutic value of snake venoms. In 1949 Haast agreed to supply Sanders with snake venoms from his serpentarium to research its therapeutic effect in neurological diseases [18].

Sanders and his team at the University of Miami were able to produce atoxic neurotropically active compounds from diverse varieties of snake venoms proposing they had antiviral properties [19]. Sanders had harbored the theory that MNT produced some interferon-like substance. MNT extracted from cobra Naja genus from South Asia, according to their findings, exhibited inhibition of at least $30 \%$ of viral plaques in the Semliki-forest virus test (U.S. Patent 4126676) while MNT from krait genus Bungarus from Southeast Asia "produced interference in pseudorabies infection" (U.S. Patent 3888977A) [20].

The University of Miami team proceeded to inoculate intracerebrally at least 4000 monkeys Macacus rhesus with Brunhilde and Lansing poliovirus, treating half of them 24 hours later with intramuscular MNT obtained from cobra Najaf flava (South Africa) and reportedly "achieving interference" and "halting" in some cases the ensuing paralysis (or death) of the animal [21,22]. In 1958 a poliomyelitis outbreak occurred in Cuba and Sanders was allowed by the sanitary authorities in Havana to travel to the island and use his MNT in affected individuals. The number of subjects that received MNT is not known. The results of this effort and the fate of the treated patients was not reported despite the Cuban Ministry of Health had registered more than 400 cases at that time [23].

Sanders left the University of Miami in 1958 and 
opened a laboratory and clinic in Boca Raton, Florida, supported by private donations: The Sanders Medical Research Foundation (SMRF). With the global advent of the Salk vaccine in 1962, MNT trials in poliomyelitis ended. Research in snake venoms continued focusing now in its possible effect in ALS. The role of viral infection in ALS had been a perennially recurring idea as one of the possible environmental factors implicated in the pathogenesis of the disease and was a plausible idea at that time [24].

From 1972 to 1982 over 1400 patients with ALS traveled to the clinic in Boca Raton to be treated with MNT. The compound was basically obtained from cobra Naja naja siamensis and injected intramuscularly at the dose of $1.3 \mathrm{ml}$ every-other-day for 6 weeks. Patients would remain in the area for the duration of the treatment. Individuals referred themselves by word-to mouth almost uniformly rejecting the philosophy of their neurologists that "there was no hope" and appreciated Sanders efforts and care. While he never misrepresented the therapy as a cure, the media sensationalized its results [25], in part due to the attractive folkloric notion of using the healing properties of snake poison to stop the progression of such a dreadful disease as ALS.

Sanders claimed MNT was a "partial" treatment for ALS reporting some of his patients stabilized (" $25 \%$ $42 \%$ ") and some ("11\%") actually showed "functional improvement" [26]. Critics insisted the concept bordered with medical credibility and the clamor for controlled trials became inevitable.

\section{Controlled Trials Sanctioned by Human Inves- tigations Committees}

Richard Tyler from Harvard University approached Sanders to obtain MNT for a double-blind trial which was conducted from 1976 to 1978. Subjects signed an informed consent to participate in the Boston study. Although Tyler included objective measurements in his trial, the final observations were based largely on subjective clinical assessments by patients. Results of 48 patients were reported. Transient improvements were noted but mortality rate was $12 \%$ during this 6 -month trial. Tyler concluded there "was no evidence to support claims that patients receive any benefit from the neurotoxin" [27].

Mostly due to insistence from the FDA, Sanders agreed to support another controlled trial. Baylor College of Medicine investigators designed a double-blind placebo-controlled study reviewed a priori with the Bureau of Biologicals (FDA) and approved by the Baylor/Methodist Hospital Institutional Review Board (called at the time 'Human Investigations Committee') in Houston, Texas. This trial included objective parameters including quantitative needle electromyography, videotape esophagram (for swallow- ing mechanism abnormalities) and pulmonary function tests including forced vital capacity and forced expiratory volume in one second.

Tyler advised the Baylor investigators a six-month trial design, similar in duration to the Boston study, in view of the progressive nature of the disease and the inconveniences and expenses that participants and care-givers had to endure. The SMRF partially sponsored this trial. The study included 64 individuals and was completed in 1979. Baylor investigators also noted transient periods of improvement, but these were more common in the patients who received placebo. Fifteen patients (five in the MNT group and ten in the placebo group) did not complete the study since eventually they became too weak to be transported. One death occurred in the MNT group and four in the placebo cohort, all taken place at home from respiratory complications attributed to the disease.

No benefit was demonstrated from the administration of MNT to this group of ALS patients [28]. The treatment was, however, safe.

Tyler had noted the close relationship of Sanders with his patients accounted probably for most of his favorable results [27].

Following the Baylor study, the FDA issue a directive to discontinue MNT treatment in ALS except (for compassionate reasons) for the few patients still receiving the neurotoxin at the Florida facility. The last doses were administered in 1982. In 1983 and in deteriorating health Sanders retired. The SMRF was dissolved.

In 1985 Sanders participated in the Congressional Hearings regarding the failure of the Tokyo Trials to indict and bring to justice the people involved in one of the great horrors of modern civilization and the ensuing cover-up by the U.S. Government. These procedures did not result in any action. Sanders died in Florida in 1988 at age 78. He had accepted the failure of his efforts as well to treat poliomyelitis and ALS with MNT with remarkable stoicism.

\section{Discussion}

The Nuremberg's Verdict indicting Nazi doctors attracted international notoriety and enabled the development of the Code for protection of human beings subjected to research. A similar callous disregard for human life had occurred in the Japanese scenario of Unit 731 but these actors escaped judgement after a young Murray Sanders naively suggested amnesty for their actions in exchange for data, later being patronized by the U.S. Government.

In 1974 the National Research Act defined IRB functions in direct response to research abuses. At the time Sanders was openly testing MNT in people with poliomyelitis (Cuba) and later in ALS patients, regulations 
were not strictly applied while the concept of compassionate treatment existed, and the patient voluntarily participated or requested the experimental therapy.

The Belmont Report in 1979 [29] emphasized the principles of fairness, respect and protection as paramount in human research.

\section{Conclusions}

The different phases of Murray Sanders' scientific work, although not widely known, reflect intertwined but concomitantly divergent philosophies involving human research during the second half of the $20^{\text {th }}$ century.

\section{Conflict of Interest}

The author has nothing to declare.

\section{References}

1. Ivy AC (1948) The history and ethics of use of human subjects in medical experiments. Science 108: 1-5.

2. World Medical Association (2013) World Medical Association Declaration of Helsinki: Ethical principles for medical research involving human subjects. JAMA 310: 2191-2194.

3. www.opcw.org/news.../history-of-thechemical-weaponsconvention

4. Williams $P$, Wallace $D$ (1989) Unit 731: Japan's secret biological warfare in World War II. Free Press, New York, NY.

5. http://www.worldfuturefund.org/

6. www.zzwave.com

7. Harris SH (2002) Factories of death: Japanese biological warfare, 1932-1945, and the American cover-up. Routledge, New York and London.

8. Albarelli HP (2001) The secret history of anthrax. WorldNet Daily.

9. Regis E (1999) The Biology of Doom: America's secret germ warfare project. Henry Holt \& Company, LLC, New York, NY.

10. Albarelli HP (2001) Fed's involvement in anthrax experiments. WorldNet Daily.

11. Matsumoto G (2004) Vaccine A: The covert government experiment that's killing our Soldiers and why Gl's are only the first victims. Basic Books, Philadelphia, PA, 29-30.

12. Barenblatt $D$ (2004) A Plague upon humanity. The hidden history of Japan's biological warfare program. Harper Collins, New York, NY.

13. Bowen J (2009) Japanese war crimes introduction-pacific war.

14. Cunliffe WH (1934-1944) Secret documents on Japanese war crimes and Japanese biological warfare, 1934-2006.

15. (2013) Turtledove H. Shiro Ishii.

16. Starr D, Lederer SE (1998) Blood: An epic story of medicine and commerce. Knopf, New York, NY, USA.

17. Peter Williams, Takao Matsumura, Shiro Kasahara, Murray Sanders, Hugh Downs (1985) Alliance of Shame. American Broadcasting Companies, New York, NY, USA.

18. Murray Sanders (1947-1957) University of Miami. Proust. Library, Miami.

19. Sanders M, Soret MG, Akin BA (1955) Antipoliomyelitis action of certain toxoids. Acta Neuroveg 8: 361-371.

20. Sanders M, Soret MG, Akin BA (1958) Neurotoxoid interference principle in pseudorabies infection: In vivo activation of aujesky virus. In: Proceedings of the VII International Congress of Microbiology. Stockholm 293.

21. Sanders M, Soret MG, Akin BA (1953) Neurotoxoid interference with two strains of poliomyelitis in rhesus monkeys. Annals of the New York Academy of Sciences 58: 3-11.

22. Murray Sanders, Manuel G Soret, Benjamin A Akin (1954) Naja flava neurotoxoid interference late in experimental poliomyelitis. The Journal of Pathology and Bacteriology 68: 267-271.

23. Beldarrain E (2013) Poliomyelitis and its elimination in Cuba: An historical overview. MEDICC Rev 15: 30-36.

24. Norris FH Jr (1977) Current status of the search for virus in amyotrophic lateral sclerosis (ALS). Neurol Neurocir Psiquiatr 18: 443-454.

25. (1976) Deadly snake venom helps victims of incurable disease. National Enquirer.

26. Sanders M, Fellows J (1975) Use of detoxified snake neurotoxin as a partial treatment for of amyotrophic lateral sclerosis. Cancer Cytol 15: 34-40.

27. Tyler R (1979) Double-blind study of modified neurotoxin in motor neuron disease. Neurology 29: 77-81.

28. Rivera VM, Grabois M, Deaton W, Breitbach W, Hines M (1980) Modified snake venom in amyotrophic lateral sclerosis. Lack of clinical effectiveness. Arch Neurol 37: 201-203.

29. (1979) The Belmont Report. Ethical Principles and Guidelines to Protect Human Research. 